republiky roku 1993. Poslední studie se pak věnuje moderním historiografickým interpretacím husitství. Zatímco v úplně první studii autor analyzuje, jaká pojmenování pro husitské období používali jeho současníci, v poslední studii nahližź na týž problém optikou historiografie 19. a 20. století. Druhý život husitství, tedy život v paměti více či méně vzdálených období, je tak zcela završen.

Výbor jako celek lze zhodnotit jako cenný př́spěvek husitologického bádání. Jednotlivé studie jistě obstojí samostatně, sestavené do výboru však představují průřezovou sondu dějin husitství samotného, i jeho druhého života. Jednotlivé bloky postupně provedou čtenáré dějinami husitství a umožní mu tak této době porozumět. $\mathrm{V}$ jednotlivých článcích nedochází k žádným zásadním obsahovým překryvům, z každého tematického oddílu krystalizují hlavní body, z nichž je možné vyjít při studiu problematiky husitství.

Kajetán Holeček

doi: $10.14712 / 23365730.2020 .8$

\title{
František Šmahel, Die Basler Kompaktaten mit den Hussiten (1436). Untersuchung und Edition
}

(Monumenta Germaniae Historica. Studien und Texte, Bd. 65), Harrassowitz Verlag, Wiesbaden 2019, XXII + 226 s., ISBN 978-3-447-11179-9, ISSN 0938-6432

Šmahelova knížečka o Basilejských kompaktátech ${ }^{1}$ se již stala klasickou, hojně citovanou. V loňském roce se odborná veřejnost dočkala o něco většího svazku, vydaného ve Wiesbadenu, který se k tématu a materiálu vrací.

Kniha je jen nepatrně upraveným německým překladem původní publikace. Text zůstal téměř nezměněn, převzaty nebyly ilustrace. Oproti Knižnici Dějin a současnosti působí proto „vážněji“. Přes první dojem pouhého přetisku při bližším pohledu zjistíme, že i na výkladovém textu autor ještě pracoval. Zařazena do překladu nebyla jen podkapitola popisující veřejné slyšení husitského poselstva v Basileji. Ta byla důležitá pro českého čtenáře, ve světových jazycích je k dispozici řada odborných titulů o koncilu, i když samotný dialog s husity je detailně analyzován a představován $\mathrm{v}$ němčině, prííp. angličtině až v poslední době. ${ }^{2}$

Ve druhé a třetí kapitole jsou naopak připojena navíc shrnutí př́slušných výkladů (s. 94-96, 122-124). První rekapitulace opakuje přehledně, kterých deset listin tvoří soubor zvaný basilejská kompaktáta. Druhé shrnutí resumuje celý výklad a zdůrazňuje význam tř́ hlavních listin a smysl celého komplexu, vazby mezi jednotlivými dokumenty a důležitost tohoto souboru pro České království.

Německá, stejně jako česká publikace obsahuje sedm exkurzi̊, resp. př́loh. V české verzi byl v prŕílohách shromážděn materiál, který měl sloužit budoucímu editorovi. Proto došlo v novém vydání $\mathrm{k}$ úpravě obsahu některých příloh. První př́loha obsahovala údaje, které ted’ zaujaly místo $\mathrm{v}$ záhlavích edice. Text př́lohy je nově věnován detailní analýze trrí originálních listin a pečetím, které listiny obsahují, nebo o nichž jsou písemné zprávy.

František Šmahel, Basilejská kompaktáta. Př́běh deseti listin (Knižnice Dějin a současnosti), Praha 2011.

2 Např. D. Coufal, P. Soukup. 
Přepracována je také druhá př́loha věnovaná rukopisnému dochování opisů kompaktát. Analýza byla rozšířena a podává daleko hlubší obrázek.

Další prrílohy zaznamenaly jen menší úpravy. Sledován je osud těchto listin a vývoj povědomí o nich (cenný je dobový výčet listin existujících v r. 1478, nebo tisky kompaktát z r. 1500 a 1513). Později zřejmě kompaktáta přestávají hrát úlohu „objektu historického vědomí“. Vracejí se k nim až historici a vydavatelé, a to jako k objektu historického bádání.

Nejdůležitější změnou německé verze publikace je její rozšiřrení o poslední třetinu obsahu, přinášející edici deseti listinných kusů, které tvoří soubor kompaktátních dohod. Když jsem před lety referovala o „Šmahelových kompaktátech“, ${ }^{3}$ vyjádřila jsem naději, že se dočkáme nové edice těchto listin. V přítomné publikaci byla tato naděje naplněna. Ediční část je uvedena vydavatelskou poznámkou, která obsahuje seznam deseti listin, které jsou dále vydány, a zevrubnou souhrnnou informaci o rukopisech, v nichž jsou dochovány jejich opisy (24 kodexů z celé Evropy, nejvíce je zastoupena Praha a Vídeň), i ediční zásady.

Samotná edice, přinášející kritické vydání 10 dokumenti̊, volí formu ad usum scholarum (upouští od nepodstatných různočtení, která by zatěžovala text pro uživatele-nefilologa). Vychází z originálů, pokud jsou k dispozici, a ze všech opisů vybírá nejkvalitnější dva až tři, ostatní jen eviduje. U každé jednotky je v záhlaví uveden způsob dochování (signatura originálu, výčet rukopisů, starých tisků), dosavadní edice a specializovaná literatura. V originální listinné formě jsou k dispozici pouze tři listiny (̌̌. I, III, a IV), všechny vystavené ze strany Českého království a uložené dnes ve Vídni (nebot' to byly zřejmě stejnopisy pro rakouského vévodu Albrechta nebo císaře Zikmunda). Zbylé kusy, vydané ze strany koncilu (legáty nebo samotným koncilem) pro České království známe jen z dobových opisů. Složitost pramenné situace komplikuje fakt, že listiny byly vydávány ve více exemplářích, existovaly také ověřené kopie (vidimusy) a jejich další opisy. Pojem originálního dochování tak má více významů. U listiny II. byl využit dokonce norimberský tisk z roku 1518 (označený siglou M, stejně jako rukopis z Třeboně, což je poněkud zavádějící). Tisk byl pořízen podle originální listinné předlohy a obsahuje i popis pečetí (s. 119, 127). Proto byl přiřazen $\mathrm{k}$ rukopisům jako další spolehlivý podklad nové edice.

Anotovaná publikace je velmi podstatným př́nosem pro bádání o závěru a výsledcích husitských válek a k sledování textové i pamět’ové tradice jedné z nejdůležitějších skupin dokumentů, které modelovaly politickou, náboženskou i sociální situaci v Českém království 15. století. Zůstaly právním základem dvoukonfesního státu jako zemský zákon i po zrušení platnosti kompaktát ze strany církve. Pro českého čtenáře není nová verze Příběhu deseti listin jen vítanou edicí textu, nebot' přináší i rozhojněnou faktografii, resp. její rozbor.

Blanka Zilynská

doi: $10.14712 / 23365730.2020 .9$

3 Studia Mediaevalia Bohemica 4/2, 2012, s. 317-318. 